\title{
A Family Affair: Marriage, Class, and Ethics in the Apocryphal Acts of the Apostles*
}

\section{ANDREW S. JACOBS}

In this essay I juxtapose a dominant culture discourse of the family, one which aims to construct an ethical center out of the marital union, with a deconstructive effort on the part of certain early Christian groups, in order to suggest that this particular Christian "antifamilial” rhetoric associated its family ethics with issues of class and social status. The Apocryphal Acts of the Apostles oppose the morally inferior upper-class family, oriented around conjugal concordia, with a status-negating Christian "family" organized around apostolic potestas.

"We can only guess what happened to marriage rules among early Christian groups." 1

\section{"A MAIDEN TAKEN CAPTIVE": CHRISTIANS AS HOMEWRECKERS}

A well-born young woman of a prominent house in Asia Minor is causing her family some distress. When the woman's fiancé comes to woo, her mother greets him with chagrin. It seems that a "strange man" has come to town and started preaching a disastrous message. "My daughter also, like a spider hanging at the window bound up by his words, is conquered by a new desire and a fearsome passion. She hangs

* A shorter version of this paper was delivered at the 1998 meeting of the Southeast Region of the SBL/AAR in Knoxville, Tenn. I wish to thank Chris Frilingos, Dale Martin, Byron McCane, Halvor Moxnes, and the two anonymous readers for JECS for their extremely helpful suggestions and criticisms.

1. Halvor Moxnes, "What is Family? Problems in Constructing Early Christian Families," in idem, ed., Constructing Early Christian Families: Family as Social Reality and Metaphor (London: Routledge, 1997), 13-41, here 30. 
upon his sayings and the maiden has been taken captive." ${ }^{2}$ When it is clear that the young woman no longer wants anything to do with her fiancé or her mother, turning away from them in silence, the whole house becomes terrified: "And they wept bitterly: Thamyris for losing a wife, Theocleia a daughter, and the maidservants a mistress." ${ }^{3}$ The young lady whose defection fractures a household from top to bottom is Thecla, heroine of early Christian "romance" and a symbol of sexual renunciation. ${ }^{4}$ Her "captor" is Paul, apostle of Jesus, whose message twice leads Thecla to capital condemnation and who himself leads a life of harassed itinerant preaching. Framed on the call of Jesus in the canonical gospels, who entices his disciples away from jobs and families, ${ }^{5}$ the Acts of Paul preach radical disjunction: "Blessed are they who have renounced this world, for they shall be pleasing to God! . . . Blessed are they who through love of God have gone out of the form of the mundane for they will judge angels and be blessed at the right hand of the Father!" 6

This disruption of households by some early Christians struck at the perceived building block of civilized society, the family. ${ }^{7}$ As some

2. Acta Pauli et Theclae 8-9. Text in R. A. Lipsius and M. Bonnet, eds., Acta Apostolorum Apocrypha (Hildesheim: G. Olms, 1959), 1: 235-72, here 242. Translated in J. K. Elliott, The Apocryphal New Testament: A Collection of Apocryphal Christian Literature in an English Translation based on M. R. James (Oxford: Clarendon Press, 1993), 364-88, here 366.

3. Acta Pauli et Theclae 10 (Lipsius-Bonnet 1: 243; Elliott 366).

4. See Averil Cameron, Christianity and the Rhetoric of Empire (Berkeley: University of California Press, 1991), 89-119, on the appeal of these "Christian romances" in the second and third centuries.

5. As in Mt 4.18-22 (II Mk 1.16-20; Lk 5.1-11) where Jesus calls first Simon Peter and Andrew away from their work as fisherman and then James and John sons of Zebedee away from their work, their father and, in Mark, their "hired men" (Mk 1.20). Disjunction from the family in the Gospels is even more forcefully stated in Lk 14.26 where the disciples are informed that they must "hate father and mother, wife and children, brothers and sisters" to follow Jesus. See Gerd Theissen, Sociology of Early Palestinian Christianity, trans. John Bowden (Philadelphia: Fortress Press, 1978), 11-12 and 61, on the sociological implications of these statements, and Elizabeth A. Clark, "Antifamilial Tendencies in Ancient Christianity," Journal of the History of Sexuality 5 (1995): 356-80.

6. Acta Pauli et Theclae 5-6 (Lipsius-Bonnet 1: 238-39; Elliott 365).

7. For a survey of "Greco-Roman" philosophical attitudes towards family, society, and marriage in particular, see Susan Treggiari, Roman Marriage: Iusti Coniuges from the Time of Cicero to the Time of Ulpian (Oxford: Clarendon Press, 1991), 185-228, tracing a similar connection between family and society from Xenophon to Plutarch. Also useful are the essays and bibliography in Beryl Rawson, ed., Marriage, Divorce, and Children in Ancient Rome (Oxford: Clarendon Press, 1991). On the Christian appropriation and manipulation of familial structures, see now the essays in Moxnes, ed., Constructing Early Christian Families. 
Christian circles became more institutionalized, this radical disruption became untenable: witness the household codes in the deutero-Pauline letters to the Colossians and Ephesians, and the careful theological mapping of Christian piety onto socially conservative conduct in the Pastoral epistles. Yet in other spheres the apostles were still wielded rhetorically and socially as "homewreckers," initiators of a message not of household order but disorder. It is important to attend to the form in which this domestic demolition is framed, as a contrast between Thecla and the North African martyr Vibia Perpetua can illuminate. ${ }^{8}$

Like Thecla, Perpetua is a "woman of good family and upbringing" brought to face public punishment for her disruptive adherence to Christian belief. Also like Thecla, Perpetua renounces her family in order to embrace a new Christian identity. The family structure "overturned" by Perpetua, however, is markedly different from that of Thecla. Instead of a jilted fiancé we have a grey-haired father pleading for mercy:

"Daughter," he said, "have pity on my gray head-have pity on me your father, if I am worthy to be called father by you; if I have brought you with these very hands into the bloom of life ... do not now surrender me to the reproaches of men. Think on your brothers, think on your mother and your aunt, think of your own son who will not be able to live after you. Set aside pride lest it overturn all of us!"”

Perpetua appears as the well-born matrona who sets aside the authority of her paterfamilias, and in so doing breaks apart the entire extended family. She abandons her father's will and seeks the will of another Father to follow instead. ${ }^{10}$ Thecla, on the other hand, abandons a potential husband to follow another man who has "captured" her in a "new desire and fearsome passion." 11 There is no father in Thecla's tale, no patria potestas to overturn, just as there is no (explicit) husband to whom Perpetua is (even metaphorically) unfaithful.

8. Peter Brown draws the comparison for different reasons in The Body and Society: Men, Women, and Sexual Renunciation in Early Christianity (New York: Columbia University Press, 1988), 158.

9. Passio Sanctarum Perpetuae et Felicitatis 5 in Herbert Musurillo, The Acts of the Christian Martyrs (Oxford: Clarendon Press, 1972), 106-31, here 112. See also Passio Perpetuae 3 (Musurillo 108).

10. There is a visual parallel between the description of Perpetua's earthly father (canis meis: Passio Perpetua 5 [Musurillo 112]) and the "heavenly father" in one of Perpetua's visions (bominem canum: Passio Perpetuae 4 [Musurillo 110]).

11. "Capture" or raptus was one way in which a woman in antiquity could be claimed by a husband: see Antti Arjava, Women and Law in Late Antiquity (Oxford: Clarendon Press, 1996), 37-41. 
The easy answer to this choice of a particular conjugal family structure under attack has been that the Apocryphal Acts promote radical sexual continence, and therefore marriage becomes the natural "enemy" which must be shamed and overturned. Recently, however, Kate Cooper has pointed out that the ascetic language of these Acts stands "poised between revolution and irrelevance," 12 and that at issue here is the moral superiority of the apostolic hero over his non-Christian counterpart. ${ }^{13}$ Even this astute observation, however, does not explain why the apostle's moral superiority is set in the familial context of marital concordia and not paternal potestas: if the canonical Paul chooses to address one of his churches "like a father with his children, urging and encouraging you and pleading that you lead a life worthy of God" (I Thess 2.11-12), why should Thecla's Paul instead seduce her away from her fiancé with "deceptive and subtle words"? ${ }^{14}$ Or why should the wily servant of a Greek proconsul, whose wife has left his bed to follow the apostle Andrew, say that she has "so given way to desire for him that she loves no one more than him" and that she has "become intimately involved with that man" ?15 While erotic titillation as a literary device should not be underestimated, there are likely more socially compelling reasons why the authors and disseminators of these Apocryphal Acts chose to aim their antifamilial discourse at the maritally-oriented family. In what follows I shall suggest that the institution of marriage in this period carried specific connotations of class and status, so that Christians might view the denigration of the conjugal family as a way of demeaning a distinctly upper-class ethics.

To this end I shall first examine the ways in which the conjugal family came to be promoted as a model of social order and stabilization among

12. Kate Cooper, The Virgin and the Bride: Idealized Womanhood in Late Antiquity (Cambridge: Harvard University Press, 1996), 52 and see 57. A brief glance at the promarriage tracts of the third-century church fathers also demonstrates an ability to maintain an ideal of both sexual continence and marriage: see Clement of Alexandria, Stromateis 3 (GCS 15: 195-247), especially 3.12.85, 3.14.94, and

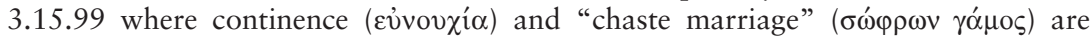
equated as the highest forms of self-control (GCS 15: 235, 239, 241).

13. Cooper, Virgin and the Bride, 58: "So the parable of the wandering ascetic and the settled householder would have been recognizable to an ancient audience as an exploration ... of Christianity's claim to moral superiority."

14. Acta Pauli et Theclae 8 (Lipsius-Bonnet 1: 241; Elliott 366).

15. Passio Andreae 25, text and translation in D. R. MacDonald, The Acts of Andrew and the Acts of Andrew and Matthias in the City of the Cannibals (Atlanta: Scholars Press, 1990), 354-57. 
the upper classes in the first centuries of the Roman Empire. ${ }^{16}$ This involved making legal marriage, historically a question of property transmission, into a matter of public dignitas, through which a man's moral character could be gauged. As marriage became transformed into a universalized ethics, however, classes for whom the legal transmission of property and the production of legitimate heirs had not previously been a concern could be implicated in this upper-class construction of the family. Legal initiatives, philosophical writings, and the fanciful Greek "romances" will be compared to show the fronts on which this transformation and universalization were occurring. Next, the Apocryphal Acts will be placed into the stream of this familial discourse as a form of class-based resistance.

\section{"LIVE TOGETHER AS PARTNERS": THE INSTITUTION OF CONJUGAL ETHICS}

The Roman historian Cassius Dio reports a public address in the year 9 C.E. by the emperor Augustus to the men of the equestrian class. Apparently there had been complaints about the severity of the laws penalizing unmarried and childless knights. Augustus responded to their concerns by dividing the members of the wealthy classes in the forum, placing the unmarried on one side and the married on the other. To the far less numerous married men he addressed words of encouragement and gratitude; to the unmarried his words were "harsh and bitter." $\mathrm{He}$ concluded his harangue against them by expressing his ideal of the Roman family to these negligent bachelors:

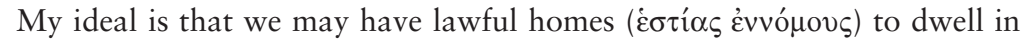
and houses full of descendants, that we may approach the gods together with our wives and children, that a man and his family should live together as partners $\left(\dot{\alpha} \lambda \lambda \dot{\eta} \lambda \operatorname{lol}^{\circ} \dot{o} \mu \lambda \hat{\omega} \mu \varepsilon v\right)$ who risk all their fortunes in equal measure, and likewise reap pleasure from the hopes they rest upon one another. ${ }^{17}$

16. My use of the term "class" throughout this essay is not intended to invoke the "high" Marxist readings of antiquity like that of G. E. M. de Ste. Croix (The Class Struggle in the Ancient Greek World from the Archaic Age to the Arab Conquests [Ithaca: Cornell University Press, 1981], esp. 19-30); I do, however, feel that substitution of "status" or similar terms for "class" (as by Wayne Meeks, The First Urban Christians: The Social World of the Apostle Paul [New Haven: Yale University Press, 1983], 53-55 and 214-15) masks the very real monetary component of senatorial and provincial aristocracy.

17. Cassius Dio, Historia romana 56.9. Text in U. P. Boissevain, ed., Cassii Dionis Cocceiani Historiarum Romanarum Quae Supersunt, 5 vols. (Berlin: Weidmann, 
Augustus' touching vision of the Roman family comes from the pen of a third-century historian; ${ }^{18}$ from the reign of Augustus what we have are a series of legislative efforts to coerce the upper class into marrying and producing new generations of Roman elites. ${ }^{19}$ These laws transferred marriage from the realm of financial transactions between propertied families into the sphere of dignitas, a factor upon which a man could establish or diminish his public "face": "Augustus ... turned what had previously been a private family responsibility into a public concern, and established the basis for marriage legislation for the next five hundred years." 20 This "public concern" marks a shift in late antique rhetoric on social status and families that has been traced on several fronts.

Some scholars in the burgeoning field of the ancient family have observed a transformation of the ideal family from a coherent unit following vertical lines of patriarchal authority to a partnership centered around the ethical union of the married couple. ${ }^{21}$ Conjugal cooperation and unity seem to replace the model of absolute authority emanating downward from the omnipotent paterfamilias. Paul Veyne first described this transformation as the psychological response on the part of elite males to their political emasculation by the new Augustan regime. ${ }^{22}$ His historical interpretation has since been challenged or nuanced on several fronts, with some denying that the Roman family "shifted" at all in late

1895-1931), here 2: 525-26. English translation from Ian Scott-Kilvert, Cassius Dio: The Roman History. The Reign of Augustus (London: Penguin Books, 1987), 229.

18. On the date of Cassius Dio's writing of his history, see T. D. Barnes, "The Composition of Cassius Dio's Roman History," Phoenix 38 (1984): 240-55.

19. The laws in question are the lex Iulia de maritandis ordinibus and the lex Iulia de adulteriis (both 18 в.C.E.) and the lex Papia-Poppaea (9 C.E.) whose institution is introduced in Cassius Dio by the cited speech of Augustus. On the rhetorical nature of this speech see the comments and references in Judith Evans Grubbs, Law and Family in Late Antiquity: The Emperor Constantine's Marriage Legislation (Oxford: Clarendon Press, 1995), 102; on the nature of the laws themselves, 96-98.

20. Judith Evans Grubbs, “'Pagan' and 'Christian' Marriage: The State of the Question," JECS 2 (1994): 361-412, here 378.

21. On the complexity of charting the structures of Roman families and for a thorough bibliography on the subject, see Dale B. Martin, "The Construction of the Ancient Family: Methodological Considerations," JRS 86 (1996): 40-60. Countering the claims of R. P. Saller and B. Shaw, "Tombstones and Roman Family Relations in the Principate: Civilians, Soldiers, and Slaves," JRS 74 (1984): 124-56, Martin provides the salutary remark that "Roman family structures were remarkably diverse and complex" (52). This does not, however, obviate ancient attempts to "normativize" family discourse, nor our subsequent attempts to analyze such discourse.

22. Paul Veyne, "La famille et l'amour sous le Haut-Empire romain," Annales ESC 23 (1978): 35-63. 
antiquity. ${ }^{23}$ Based on his study of imperial rescripts concerning actual marriages, historian of Roman law Antti Arjava dismisses Veyne's suggestion that even the ideal of marriage changed: "There is no sign of any change during the principate or later in the way the marital bond was perceived." ${ }^{24}$ Arjava's reading of legislative realia, however, does not obviate the rhetorical manipulation of a marital ideal by interested parties, even if there is no "real" shift in the legal construction of husband and wife. ${ }^{25}$ This rhetorical manipulation is precisely where we must locate the often conflicting and confusing literature that attempts to idealize marriage as the defining feature of the correct (upper-class) family and, by extension, the correct microcosm of (aristocratic) society. ${ }^{26}$

One theme that permeates our sources is the moral interiorization of the conjugal bond of concordia: marriage is not just as a procreative or monetary transaction between families, but an ethical union between individuals. Veyne dubs this "the birth of the couple." ${ }^{27}$ In the early

23. Suzanne Dixon, "The Sentimental Ideal of the Roman Family," in Rawson, ed., Marriage, Divorce and Children, 99-113, places the "shift" in the late Republic, and Evans Grubbs, "'Pagan' and 'Christian' Marriage," 370, attributes it to the "provincial" Flavians. Veyne's psychology is questioned by Aline Rousselle, "The Family Under the Roman Empire: Signs and Gestures," in André Burguière et al., eds., A History of the Family, vol. 1: Distant Worlds, Ancient Worlds (Cambridge: The Belknap Press of Harvard University Press, 1996), 269-310, esp. 275-77.

24. Antti Arjava, Women and Law, 127. Arjava does at other points allude to "conflicting ideals for the conjugal relationship ... in the Roman upper classes" (111) but without much further elaboration. He also tracks an interesting financial parallel to Veyne's essentially rhetorical construction: the shift over this same period in Roman law "from a purely dotal marriage system" (i.e., where only the bride brings property to the groom's house) "to a system in which both bride and groom made a substantial contribution to the common household" (57). It is possible that this financial shift follows the ideological curve of Veyne's rhetorically invented "happy couple."

25. Cooper, Virgin and the Bride, 3, makes just this point in her critique of Veyne's position and the use of it by Foucault in his History of Sexuality: "Philosophers might debate the best view of marriage not because of a change in the structure of the aristocratic family but because of a jostling for position among schools." On the network and reciprocal influence of Veyne, Foucault, and Peter Brown in the late 1970s and early 1980s, see Averil Cameron, "Redrawing the Map: Early Christian Territory After Foucault,” JRS 76 (1986): 266-71, esp. 267.

26. For a sociological study of competing family structures, especially in relation to class, see Françoise Lautman, "Differences or Changes in Family Organization," in Robert Forster and Orest Ranum, eds., Family and Society: Selections from the Annales: Economies, Sociétés, Civilisations, trans. Elborg Forster and Patricia Ranum (Baltimore: Johns Hopkins University Press, 1976), 251-61.

27. Veyne, "Famille et l'amour," 48: "Alors naît le couple." Cooper, Virgin and the Bride, 38, points out that the topos of the nonmaterial "charms" of marriage can be 
imperial period, the rhetoric of conjugal ethics went from a charming accoutrement of marriage to its theoretical underpinning and justification. I shall examine first legal materials, which focus on the containment of wealth but may also have attempted to exercise a certain moral authority; next the philosophical tractate Coniugalia praecepta, written by the first-century homme de lettres Plutarch to philosophize a young couple's nuptial bliss; and finally the so-called "Greek romances," which encapsulate much of the marriage rhetoric of both the jurists and the philosophers into an exciting narrative that could spread the moral discourse of marriage quite far afield..$^{28}$ The aim here is to establish how "marriage" became the particular ethical emblem of the upper-class family.

The Augustan legislation was never meant to mobilize the entire citizenry to become married with children: his efforts were directed at the senatorial classes, whose sons and daughters were not producing sufficient legitimate progeny to perpetuate the workings of the principate. The main points of the laws were: transformation of adultery and stuprum (illicit sex) into public crimes tried in court; stricter regulation of divorce; forfeiture of inheritance by unmarried or childless individuals; and prohibition of certain unions based on degree of relation and difference in status. ${ }^{29}$ This series of leges is concerned strictly with matrimonium, that is, the legal form of marriage between two consenting parties ${ }^{30}$ that will result in legitimately conceived heirs: "In fact, the

traced back to the Odyssey. See also Treggiari, Roman Marriage, 185: "The Greek moral philosophers found in Homer the marriage of Odysseus and Penelope as a recipe for perfection and the marriage of Paris and Helen as the recipe for failure."

28. Simon Goldhill, Foucault's Virginity: Ancient Erotic Fiction and the History of Sexuality (Cambridge: Cambridge University Press, 1995), has to some extent anticipated $m e$ in this comparative effort, deliberately moving from "Augustus' legislation on marriage and adultery" (113) to discuss "ideals of marriage, that key institution of normative sexual discourse" through readings of the ancient romances and Plutarch's other notable text on married love, the Amatorius (discussed more fully below). Goldhill's interest in marriage, however, is as a normative locus of desire and sexuality and not as a class-based social and ethical institution.

29. For a concise summary see Evans Grubbs, Law and Family, 94-96; for more detailed discussion and bibliography on the laws, see Treggiari, Roman Marriage, 6080 ; on the difficulties in reconstructing the exact wording and function of these laws, see Arjava, Women and Law, 77-78.

30. Jurists agree that "consent" is a central component of iustum matrimonium, for example Digests 23.2.3 (Paul) (text in Theodor Mommsen and Paul Kruegger, eds., and Alan Watson, trans., The Digest of Justinian, 3 vols. [Philadelphia: University of Pennsylvania Press, 1985]), here 2: 657); but lawmakers assumed consent even when parties later sought annulment: "If by his father's force (cogente) 
Augustan legislation was originally designed to promote marriage and child-bearing (and to discourage extramarital sexual activity) among those Romans whose moral and social behaviour was of the greatest importance to Augustus-that is, the Roman senatorial aristocracy, and the wealthier and more socially distinguished classes in general." ${ }^{31}$ The language of jurists commenting on these laws can be generalized, especially when considering the ethics of marriage: "Marriage is the union of a man and a woman, a partnership for life involving divine as well as human law." ${ }^{32}$ Most of the surviving pieces of the lex Iulia et Papia (as this conglomeration of laws came to be known), however, restrict any ethical imperatives to their appropriate social sphere. One jurist cites a long passage from the legislation directed squarely at the highest aristocracy:

A senator, his son, or his grandson, or his great-grandson by his son shall not knowingly or fraudulently become betrothed to marry or marry a freedwoman, or a woman who is or has been an actress or whose father or mother are or have been actors. Nor shall the daughter of a senator, his granddaughter by his son, or great-granddaughter by his grandson become betrothed to or marry, knowingly or fraudulently, a freedman, or a man who is or has been an actor or whose father or mother is or has been an actor. $^{33}$

The commentator Paul softens the legislation by noting that if the freeborn woman's parents take up acting after the marriage "it would be most unfair to divorce her since the marriage was respectable (bonestate) when contracted, and there may already be children." By labeling such inappropriate unions not only legally void but also morally shamefulstuprum - these laws invest marriage with an ethics that lies at the heart of the conjugal union yet is de facto (and de iure) restricted to a particular social location: note that there is little or no concern as to

he marries a women whom he would not have married if left to his own free will (sui arbitrii), nevertheless he has contracted legal marriage (matrimonium), which could not have taken place between unwilling parties (invitos): he seems to have wanted to do it" (Digests 23.2.22 [Celsus] [Watson 2: 660]).

31. Evans Grubbs, Law and Family, 105.

32. Digests 23.2.1, attributed to Modestinus, a third-century jurist: "Nuptiae sunt coniunctio maris et feminae et consortium omnis vitae, divini et humani iuris communicatio" (Watson 2: 657).

33. Digests 23.2.44 (Paul) (Watson 2: 663). Several other prohibitions center on senatorial dignitas: Digests 23.2.23 (Celsus), 23.2.27 (Ulpian), 23.2.33 (Marcellus), 23.2.43 (Ulpian), 23.2.47 (Paul), 23.2.49 (Marcellus) (Watson 2: 660, 661, 662, 664). 
whether these restricted lower-class groups themselves ever marry and produce children..$^{34}$

Augustus' legislation was to a large extent framed in moralizing terms, perhaps as a form of noblesse oblige: the laws encouraged constant scrutiny of a man's dignitas by his upper-class neighbors, even prompting senatorial families to inform on those in violation of the marital prescriptions. ${ }^{35}$ In this respect we should not entirely dismiss Cassius Dio's reconstruction of Augustus' public defense of his legal program. ${ }^{36}$ While jurists do echo the Augustan ideal that marriage as an institution should be respectable, ${ }^{37}$ more often they reflect the resistant mood of the coerced aristocracy by shifting the focus of their commentaries from concerns ethical to monetary. ${ }^{38}$ The moralizing tone of the Augustan legislation becomes so hard to hear through the barrage of complaints

34. As Jane F. Gardner, Women in Roman Law and Society (Bloomington: Indiana University Press, 1986), 57, points out: “Augustus' legislation on marriage and on adultery had created several categories of women who were themselves free and of citizen status, but either had no conubium [i.e., right to marry legally] at all, or no conubium with certain categories of citizens."

35. Reported with irritation by Tacitus, Annales 3.25-28 (LCL 2: 562-68), who uses the public disturbance generated by these laws that attempted "to popularize marriages (coniugia) and the rearing of children" to critique the checkered history of invasive Roman legislation. On the moral framing of Augustus' legislation and its coding as "revival" of purer times, see Catharine Edwards, The Politics of Immorality in Ancient Rome (Cambridge: Cambridge University Press, 1993), 35-38, 53-58.

36. On Cassius Dio's sources and representation of the Augustan period, see Fergus Millar, A Study of Cassius Dio (Oxford: Clarendon Press, 1964), 83-102, esp. 100102. Cassius Dio may be not unreasonably importing senatorial reaction to a revival of the adultery laws by Septimius Severus at the end of the second century: see Cassius Dio, Historia Romana 76.16 (Boissevain 3: 371) and the sneering comments of Tertullian, Apologeticus 4.8 (CCL 1: 93) (both cited by Barnes, "Composition," 243).

37. See Digests 23.2.13 (Ulpian), 23.2.14.2 (Paul), 32.2.42 (Modestinus) (Watson 2: 658-59, 662). Of course, behind such designations may lie the understanding that it is the honestiores (nobles) who will act with honestas.

38. Ulpian refers often to the lex Iulia et Papia, yet only briefly treats the dignitasbased restrictions on senatorial marriage while going on at length about the ramifications of these laws on minute aspects of inheritance: Regulae Ulpiani 13.1-2 (text in S. Riccobono et al., eds., Fontes Iuris Romani Antejustiniani [FIRA] [Florence: S. A. G. Barbèra, 1968] 2: 261-316, here 277) on the marriages of "senatores . . . liberique eorum"; Regulae Ulpiani 11.20, 14, 16.1-3, 18, 19.17, 24.12, 24.30, 29.3-5 (FIRA 2: 275, 277, 278-81, 291, 293, 300-301) on dowry, legacy, intestacy, and wills. On the resistance of the aristocracy to Augustus' coercion, see also Suetonius, De Vita Caesarum: Divus Augustus 34 (LCL 1: 176-78). For a study of similar aristocratic manipulation of marital regulation, see Pierre Bourdieu, "Marriage Strategies as Strategies of Social Reproduction," in Forster and Ranum, eds., Family and Society, 117-44, esp. 135. 
and commentary that Michel Foucault dismisses it as a significant factor in late ancient ethics:

One can relate [new attitudes to the self and sexuality] to certain efforts on the part of political power to raise moral standards in a more or less authoritarian way. ... [I]t would doubtless be incorrect to see in these measures and these ideas the beginning of a centuries-long evolution that would lead to a regime in which sexual freedom would be more strictly limited by institutions and laws, whether civil or religious. ${ }^{39}$

Foucault's separation between legal initiatives and philosophical propositions may be forced, however: it is difficult to disentangle the "authoritarian" strategies of Augustus ideologically from the more ingratiating exhortations of philosophers. ${ }^{40}$

Plutarch's gently framed Coningalia praecepta, a cerebral gift to some newlywed friends to "swell the nuptial song" 41 in the bridal chamber, proclaims through valorization of "philosophy" that ethics both produces and is produced within the matrimonial state. ${ }^{42}$ This "philosophical" shading of the conjugal union echoes the ethical coercion of Augustus' legal reforms, as moral development is articulated by Plutarch as the "duty" of well-brought up individuals who get married. The gift of this discourse itself is symbolic of the philosophical and ethical union of marriage:

I am sending it as a gift for you both to possess in common, and at the same time I pray that the Muses may lend their presence and cooperation to Aphrodite, and may feel that it is no more fitting for them to provide a lyre or lute well attuned than it is to provide that the harmony which concerns

39. Michel Foucault, History of Sexuality, vol. 3: The Care of the Self, trans. Robert Hurley (New York: Vintage Books, 1986), 40.

40. Stated with clarity by Edwards, Politics of Immorality: "Scholars tend to treat Roman law as a domain independent of what is labeled literature, a series of practical responses to practical problems. It should rather be seen as a symbolic discourse, bearing as much or as little relationship to patterns of behavior in ancient Rome as the effusions of Roman moralists, and in dialogue with, indeed part of, moralistic discourse" (35).

41. Plutarch, Coningalia praecepta Preface (138B; LCL 2: 298).

42. On the ethical symbolism of marriage in Plutarch, see Cooper, Virgin and the Bride, 5-11; Lisette Goessler, Plutarchs Gedanken über die Ehe (Zürich: Buchdruckerei Berichthaus, 1962) examines the Amatorius, Coniugalia praecepta, and several Lives to trace Plutarch's marriage theory; Foucault, Care of the Self, 193-210; and for a different reading of the treatise's social location, see Cynthia Patterson, "Plutarch's 'Advice on Marriage': Traditional Wisdom through a Philosophical Lens," ANRW II.33.6 (1992): 4709-23. 
marriage and the household shall be well attuned through reason, concord,

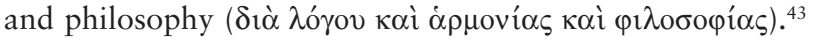

The Muses, whose "nuptial song" has in a traditional way initiated this marriage, ${ }^{44}$ are here drafted into a philosophical role, using their "harmony" to phrase marriage as an ethical and reasonable union of souls. Philosophy becomes the musical "theme" of marriage, through which it "chants a spell" over those entering a "lifelong partnership

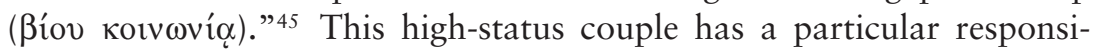
bility to marriage because they have been "brought up in the atmosphere of philosophy," 46 and it is to the ethics of "harmony" and "reason" that they must therefore dedicate their union. Such gross motives as money or even reproduction (standard reasons for marriage in the ancient world) are dismissed as inferior to the glorious commingling of spirits for which matrimony is intended:

The marriage of the couple in love with each other is an intimate union; that of those who marry for dowry or children is of persons joined together; and that of those who merely sleep in the same bed is of separate persons

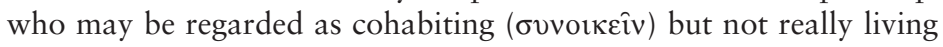
together $(\sigma v \mu \beta$ เovv $){ }^{47}$

As has been observed, Plutarch retains a notion of hierarchy within this "symbiosis":48 it is the husband's duty to "lead" his wife into a state of higher morality. Marriage is intended to be an "ethical schoolhouse $\left(\delta 1 \delta \alpha \sigma \kappa \alpha \lambda \varepsilon i \hat{\text { ov }} \varepsilon \dot{v} \tau \alpha \xi^{\prime} \alpha \varsigma\right)$ " in which the groom teaches his bride about "virtue, devotion, constancy, and affection." 49

This schoolhouse replaces such common structures of marriage as the marriage bed. Plutarch insinuates his ethical ideals into the reproductive efforts of husband and wife: "Man and wife ought especially to indulge in this [procreation] with circumspection, keeping themselves pure from all unholy and unlawful intercourse with others, and not sowing seed

43. Plutarch, Coningalia praecepta Preface (138C; LCL 2: 300).

44. Presumably sexually: Plutarch compares his discourse to the "horse rampant" flute music used to "arouse ardent desire" (Coningalia praecepta Preface [138B; LCL 2: 198]). See Goessler, Plutarchs Gedanken, 45.

45. Plutarch, Coningalia praecepta Preface (138C; LCL 2: 298).

46. Plutarch, Coningalia praecepta Preface (138C; LCL 2: 298). On the curial status of the recipients' families, see Bernadette Puech, "Prosopographie des amis de Plutarque," ANRW II.33.6 (1992): 4831-93, here 4842-43, 4849, 4873, 4879-83.

47. Plutarch, Coningalia praecepta 34 (142F-43A; LCL 2: 324).

48. As by Treggiari, Roman Marriage, 224-26.

49. Plutarch, Coniugalia praecepta 46-47 (144F-45A; LCL 2: 344-46). 
from which they are unwilling to have offspring." ${ }^{50}$ Plutarch further compares the fatherless uterine growths found in some women and the husbandless cogitations of wives in order to supplant physical reproduction altogether: "Great care must be taken that this sort of thing does not take place in women's minds. For if they do not receive the seed of good doctrines and share with their husbands in intellectual advancement, they, left to themselves, may conceive many untoward ideas and low designs and emotions." 51 The husband's role as literal inseminator is replaced by Plutarch with a philosophical insemination: it is not only that marriage provides a convenient opportunity for wives to advance in philosophical education and wisdom along with their husbands, it is the very nature of marriage to be born from and in turn "reproduce" a union of "minds." As his own version of a "love-song" draws to a close, Plutarch once again invokes the Muses in the service of "education and

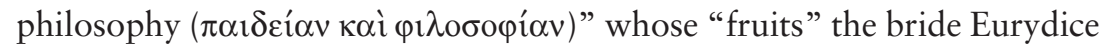
is to enjoy. ${ }^{52}$

It is unlikely that Plutarch imagines Pollianus and Eurydice would never have children or fulfill their civic duty in regards to a full and prosperous oikos: at one point Plutarch makes the very conventional observation that "a man therefore ought to have his household well harmonized who is going to harmonize state, forum, and friends." ${ }^{53}$ His rhetoric, however, shifts the theoretical underpinnings of marriage in the same direction as the Augustan legislation: from the financially constituted union of variously interested patresfamilias to the "philosophically"-oriented union of minds, "an institution particularly able to foster moderation and stability in the participants." ${ }^{54}$ It is important that the ethical internalization of this philosophy remains within a restricted social sphere, as it was in the legislative proscriptions against certain

50. Plutarch, Coningalia praecepta 42 (144B; LCL 2: 332).

51. Plutarch, Coningalia praecepta 48 (145E; LCL 2: 338-40).

52. Plutarch, Coniugalia praecepta 48 (146A; LCL 2: 342). Goessler notes that both the Amatorius and Coniugalia praecepta share this "Ringkomposition" (Plutarchs Gedanken, 45).

53. Plutarch, Coningalia praecepta 43 (144C; LCL 2: 332). See also Plutarch, Amatorius 754B-C (LCL 9: 306-441, here 336): "Moreover, the right age and proper time for marriage are suitably matched as long as both parties are able to procreate." This comes from Plutarch himself, as "reported" in the dialogue by his son some years later-a complicated dialogical fiction that further acts to weld philosophy and procreation in a discourse on love and marriage. Goessler proposes that the Amatorius lays the groundwork for which the Coningalia praecepta expresses the philosophical frame: Plutarchs Gedanken, 44-69.

54. Cooper, Virgin and the Bride, 11, emphasis mine. 
unions. Marriage remains the elevated ethics of an upper-class family. It is the Greek "romance" novels, a literary genre that narrativizes the legislative and philosophical efforts to promote the maritally-centered family, that camouflage the class-specific nature of that family. ${ }^{55}$

The world of the Greek romance is a curious mixture of fantasy and reality: while its heroes and heroines participate in adventures that could justly be called swashbuckling, it is clear that their proper place remains the entirely familiar. Their travels may take them to the court of the Great King of Persia, ${ }^{56}$ or to the squalid hut of a goatherd, ${ }^{57}$ or even to battle on the deck of a pirate ship, ${ }^{58}$ but always the final destination is home and hearth, symbolized and actualized by marriage, the "happy ending" par excellence of the Greek romance. ${ }^{59}$ The extremities of the social disruption within the novels underscore the cohesion triumphantly restored at their conclusions. ${ }^{60}$ Marriage between the protagonists (either celebrated at the beginning and tragically interrupted, or deferred by circumstance until the end of the story) is, as has been frequently noted, "the social backbone of the romances." ${ }_{61}$ Marriage is in fact so omnipresent in the romances that merely cataloguing its appearances

55. For the growing literature on the novels, see the bibliography of David Konstan, Sexual Symmetry: Love in the Ancient Novel and Related Genres (Princeton: Princeton University Press, 1994).

56. Chariton, Chaireas and Kallirhoe 5.8-6.9. Text in Warren E. Blake, ed., De Chaerea et Callirhoe Amatoriarum Narrationum Libri Octo (Oxford: Clarendon, 1938), here 74-77. Translation by B. P. Reardon in idem, ed., Collected Ancient Greek Novels (Berkeley: University of California Press, 1989), 17-124.

57. Xenophon of Ephesus, An Ephesian Tale 2.9-11. Text in Georges Dalmeyda, ed., Les Éphésiaques ou Le Roman d'Habrocomès et d'Anthia. (Paris: Editions Belles Lettres, 1926), here 28-31. Translation by Graham Anderson in Reardon, Greek Novels, 125-69.

58. Achilles Tatius, Leukippe and Kleitophon 3.9-10. Text in Jean-Phillippe Garnaud, ed., Le Roman de Leucippé et Clitophon (Paris: Editions Belles Lettres, 1991), here 84-86. Translation by John J. Winkler in Reardon, Greek Novels, 170284.

59. On "marriages as happy ending," see Judith Perkins, The Suffering Self: Pain and Narrative Representation in the Early Christian Era (London: Routledge, 1995), 41-76.

60. See Perkins, The Suffering Self, 46: "These romances filled with travel, adventure, and final union idealize social unity"; also Cooper, Virgin and the Bride, 34: "Since love and disruption were linked in the ancient imagination, romance was a narrative form well suited to the exploration of the limits of an established identity."

61. Brigitte Egger, "Women and Marriage in the Greek Novels: The Boundaries of Romance," in James Tatum, ed., The Search for the Ancient Novel (Baltimore and London: Johns Hopkins University Press, 1994), 260-80, here 260. 
borders on the redundant: to a great extent, the novels are marriage, portrayed in an exciting narrative. ${ }^{62}$

Brigitte Egger has argued that, in comparison with Roman and provincial law, the Greek romances are socially archaizing, projecting their heroines into a fictitious legal status more reminiscent of an Attic past than a Hellenistic present. ${ }^{63}$ She posits that under the thin veil of the erotic and sentimental love story, "marriage" in the end works to "factually debilitate ... [the] image of women." ${ }^{64}$ Egger operates, however, from a fairly optimistic view of the legal prospects of married women in the Roman Empire; while she may find Heliodorus' legal fiction of adultery as capital crime fanciful and misogynistic (a point I would not dispute), this extreme position on the moral imperatives of marriage resonates with the ethical coercion exercised by the Augustan legislation. ${ }^{65}$ Similarly, the great attention to fidelity and legitimate procreation within the novels speaks to the same ethical "duties" promulgated by Augustus' laws. ${ }^{66}$ The protagonists of the romances could serve as exemplary good citizens who of their own ethical will fall in love and "live together as partners."

Marriage is also construed, as in Plutarch's philosophical treatises, as the locus of advancement made available uniquely to the married couple.

62. See the excellent discussions in Perkins, Suffering Self, 41-76 and Cooper, Virgin and the Bride, 20-44, which focus more on social institutions and power than, as other modern works, on sexuality per se.

63. Egger, "Women and Marriage," 266-74: "Often, the law tends to be more conservative than other aspects of reality and expressions in mentality; but in the case of women in late Hellenistic society, it is not so conservative and constraining a discourse as that of Greek romance" (274).

64. Egger, "Women and Marriage," 273; romances, she believes, are at times "even more frauenfeindlich than Attic law" (270).

65. Egger, "Women and Marriage," 279 n. 48; see Heliodorus, An Ethiopian Story

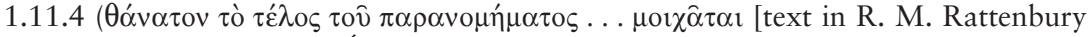
and T. W. Lumb, ed., Les Éthiopiques: Théagène et Chariclée, 3 vols. (Paris: Edition Belles Lettres, 1935-43) here 1: 17; translation by J. R. Morgan in Reardon, Greek Novels, 353-588]; Egger also refers to 1.17.5, but it is not clear that Demainete's death there is imagined as commensurate with her legal "punishment" [Rattenbury and Lumb 1: 27]). For a third- or fourth-century discussion of when husbands and fathers can put adulterers and adulteresses to death based on the leges Iuliae de adulteris coercendis, see the Mosaicarum et Romanarum Legum Collatio 4.2.1-12.8 (FIRA 2: 552-56), discussed with other Digests passages in Treggiari, Roman Law, 282-85.

66. Cooper, Virgin and the Bride, 43, suggests that the eroticism of the novels "should be understood as an encouragement to fertility similar in aim to the Augustan marriage legislation." Goldhill, Foucault's Virginity, 113, also makes this connection. 
Simon Goldhill, whose essays on ancient erotic writings attempt to supplement Foucault's History of Sexuality, dismisses Foucault's suggestion that the Amatorius should be read apart from other literature as a "turning point in the history of desire": "Its significance is perhaps better seen as the fullest statement of an ideological or theoretical self-situating that runs in different guises through the various texts I have been discussing and finds its most developed narrative expression in the great sophistic novels of Longus, Heliodorus and Achilles Tatius." ${ }^{67}$ The philosophical "guise" of Plutarch's Coningalia praecepta and Amatorius is transformed in the novels into a romanticized contrast between "successful" marriages and "doomed" homoerotic affairs. ${ }^{68}$ This does not so much value "heterosexual" over "homosexual" desire, but rather juxtaposes types of relationships in which desire may be successfully actuated. ${ }^{69}$ The married couple survives extraordinary perils to arrive at a position at the center of society, the conjugal union, superior and triumphant, while the much less harshly tested relationships of unmarried couples end in tragedy and death. In Achilles Tatius' Leukippe and Kleitophon, the hero's cousin Kleinias laments that his "boyfriend"

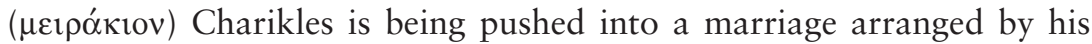
father. Kleinias, outraged, launches into a diatribe against women and marriage reminiscent of Plutarch's Amatorius; as he is wrapping up, news comes that Charikles is dead, having been thrown by the horse Kleinias gave him. ${ }^{70}$ At the funeral, the eulogy of Charikles' father reminds the reader what his son's fate should have been: "O groom and

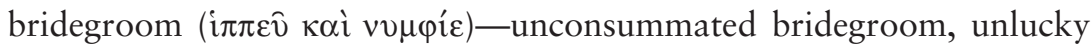
chevalier. Your bridal chamber is the grave, your wedlock is with death, your wedding march a funeral hymn, your marriage song this dirge." Kleinias' own lament makes it clear that their relationship, explicitly counterposed to legal marriage, is the cause of this tragedy: "O cruel

67. Goldhill, Foucault's Virginity, 144; see Foucault, Care of the Self, 197-99, where he describes the Amatorius as the proponent of a new "unitary erotics."

68. Konstan, Sexual Symmetry, 29, calls the affairs "doomed"; John J. Winkler, translator of Achilles Tatius' Leukippe and Kleitophon, in a note also refers to these "tragic gay subplots" (Reardon, Greek Novels, 185).

69. See for instance Goldhill, Foucault's Virginity, 76-92, where these erotic logoi are analyzed "as providing a particular counterpoint to the framing tale-as foreshadowing events ... offering thematic focuses, constructing paradigms which help articulate the place of the hero and heroine within the realm of erotic discourse" (81).

70. Achilles Tatius, Leukippe and Kleitophon 1.7-12 (Garnaud 12-22).

71. Achilles Tatius, Leukippe and Kleitophon 1.13.5 (Garnaud 23; Winkler, 186). 
fate! I bought you your murderer and gave him to you as a gift!"72 Later in the same novel, as Leukippe and Kleitophon elope with Kleinias' aid, they encounter an Egyptian named Menelaus, who also tells the story of causing his male lover's death in a hunting accident: "He died in the embrace of the very arms that had killed him." 73 This tragedy, set in the context of Kleitophon's erotic journey to the marriage bed and reinforced by a retelling of Kleinias' own tale and a mock-Platonic dialogue on the virtues of boy-love versus woman-love, ${ }^{74}$ again acts as negative foil to the properly constituted marital relationship which is the novel's inevitable conclusion.

David Konstan has proposed that the Greek novels alone of Hellenistic amatory literature conform their protagonists' relationships to a model of "sexual symmetry," in which the male and female partners are socially and romantically matched. The "pederastic paradigm," characterized by an asymmetry between erastēs and erömenos, is set forth as a negative counterpart, "doomed" to failure. ${ }^{75}$ Conjugal "happy endings" are naturalized in the narrative, in much the same way that Plutarch depicted marriage as the natural site of philosophical progression. Konstan further remarks, however, that social status is likewise made symmetrical in a way that masks its significance altogether in the maritally-driven novel:

Divisions of class and status marked ancient society as well as modern, and are reflected in the narrative presuppositions of New Comedy, epic, and other classical genres. But the Greek novelists, uniquely as it seems, elected to portray reciprocal erotic relationships between social equals and thereby defined for the genre a problematic involving love and fidelity that excluded a primary concern with issues of status or rank. ${ }^{76}$

Status and rank are unrealistically "deproblematized," as if they were not factors in the negotiation of a proper marriage. This veiling of class in the ethics of conjugal union is illustrated by the house slaves Leukon and Rhode, companions of the protagonists Habrokomes and Anthia in Xenophon of Ephesus' Ephesian Tale.

Leukon and Rhode appear sporadically throughout the novel, making

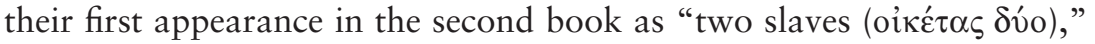

72. Achilles Tatius, Leukippe and Kleitophon 1.14.3 (Garnaud 24; Winkler, 186).

73. Achilles Tatius, Leukippe and Kleitophon 2.34.5 (Garnaud 66; Winkler, 205).

74. Achilles Tatius, Leukippe and Kleitophon 2.35-38 (Garnaud 67-72).

75. Konstan, Sexual Symmetry, 14-59.

76. Konstan, Sexual Symmetry, 218; see also 186: "[The Greek novel] abolishes the tension between eros and marriage that informs all previous genres." 
not necessarily even sharing a relationship with each other. ${ }^{77}$ Later, partaking in the misfortunes of their master and mistress, they are sold together in Lycia "to an old man who gave them every attention and treated them as his own children." 78 When next we meet this pair it is in the last book of the novel where they are described as the "companions

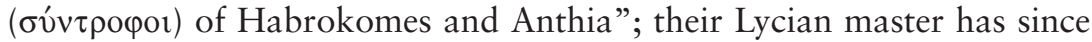
died and "left his large estate to them." the role of wealthy householders, traveling to Rhodes where they make offerings to Helios and erect a "pillar inscribed in gold" with their own names. ${ }^{80}$ The erection of such a monument, in normal circumstances, would seem the act of a well-to-do married couple: ${ }^{81}$ in fact, Leukon and Rhode's monument stands next to a "gold panoply" that had earlier been dedicated by Anthia and Habrokomes themselves. ${ }^{82}$ On Rhodes, Leukon and Rhode are instrumental in reuniting Anthia and Habrokomes after their separation and adventures; upon recognizing Habrokomes they "made over their possessions to him, took care of him, looked after him, and tried to console him." 83 At this point they stand halfway between their former status as slaves and their recent status as the "happy couple": their own conjugal bliss acts as a salve for the temporarily solitary Habrokomes. When they discover Anthia mourning next to the offerings at Helios' temple, their exclamation restores the "real" happy couple to the center of the narrative while resituating themselves in a position of servitude: "Mistress Anthia, we are your

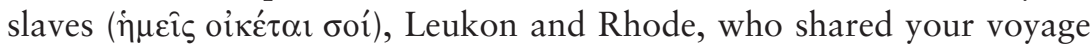
and the pirate lair. ... Have courage, mistress; Habrokomes is safe, and he is here, always mourning for you!" ${ }^{84}$ That night the protagonists and their entourage break up into what seem to be comparable couples: "Leukon with Rhode, Hippothous with the handsome Kleisthenes . . . Anthia with Habrokomes." ${ }^{85}$ Kleisthenes, however, is soon after adopted by Hippothous, and Leukon and Rhode give over the rest of their

77. Xenophon of Ephesus, Ephesian Tale 2.2.3 (Dalmeyda 22; Anderson 139).

78. Xenophon, Ephesian Tale 2.10.4 (Dalmeyda 30; Anderson, 144).

79. Xenophon, Ephesian Tale 5.6.3 (Dalmeyda 64; Anderson, 162).

80. Xenophon, Ephesian Tale 5.10.6 (Dalmeyda 71; Anderson, 166).

81. See Cooper, Virgin and the Bride, 38-43, where she analyzes the social significance of Daphnis and Chloe's munificence, which frames Longus' novel.

82. Xenophon, Ephesian Tale 1.12.2-3 (Dalmeyda 16).

83. Xenophon, Ephesian Tale 5.10.12 (Dalmeyda 71-72; Anderson, 167).

84. Xenophon, Ephesian Tale 5.12.5 (Dalmeyda 74; Anderson 168).

85. Xenophon, Ephesian Tale 5.13.6 (Dalmeyda 75; Anderson, 169). 
possessions to Anthia and Habrokomes, or, as Xenophon phrases it, "share everything with their companions." 86

Exactly what position Leukon and Rhode hold in the household of Anthia and Habrokomes at the end of the Ephesian Tale is remarkably unclear: one can assume that they retain their freedom as granted by their Lycian master's will, perhaps enjoying conjugal bliss alongside their former owners and masters; or one could imagine that narratively their own conjugal union, like their wealth, was merely held "in trust" for the true protagonists during their unfortunate separation. Either way, a fluidity has been inscribed into the marital discourse of the novel: the happiness of the maritally centered household, the upper-class "ethics of the couple," has for a brief moment slipped through the status-oriented cracks that the Augustan legislation and Plutarch's philosophical tracts sought to cement up. As Konstan remarked, class and status as issues in proper marriage have been veiled, in a genre that might itself extend deeper into the lower social and economic classes of imperial society. ${ }^{87}$ By "romancing" an ethics of the conjugal family, the Greek novel seems to open up an imaginative ethical space, however small, beyond the socioeconomic sphere in which it was fabricated. Here is where we can begin to trace the ethical and narrative intervention of the so-called Apocryphal Acts of the Apostles.

\section{"HER OWN PROPER KINSHIP": MARRIAGE AND FAMILY IN THE APOCRYPHAL ACTS}

As in the Greek romance novels, there is sustained attention to marriage in the apocryphal literature recounting the lives and deeds of the apostles. Social historians once attributed this to the nature of the authors and readers of the Apocryphal Acts: with such interest in the "liberation" of women from a repressive marriage bond into the freedom of a radically egalitarian Christianity, these texts must have originated from and for various women's groups. ${ }^{88}$ More recent studies have been

86. Xenophon, Ephesian Tale 5.15 (Dalmeyda 76-77; Anderson, 169).

87. Ewen Bowie, "The Readership of Greek Novels in the Ancient World," in Tatum, ed., Search for the Ancient Novel, 435-59, demonstrates with some acuity that the novels were likely intended for a sophisticated, educated (pepaideumenoi) audience, but concedes that "a number of points could support the notion that the readership of the novel may have spilled over ... to reach a slightly wider circle" (441).

88. Stevan Davies, The Revolt of the Widows: The Social World of the Apocryphal Acts (Carbondale: Southern Illinois University Press, 1980) passim, esp. 95-129, first 
less optimistic about this direct recovery of a female (and even feminist) point of view. For Peter Brown, these texts "reflect the manner in which Christian males of that period partook in the deeply ingrained tendency of all men in the ancient world, to use women 'to think with." "89 Similarly, Kate Cooper contends that "the challenge posed here by Christianity is not really about women or even about sexual continence, but about authority and the social order." 90 Cooper analyzes "the apostle's proposal of sexual abstinence" in the Apocryphal Acts as a means to a countercultural and subversive end: the political disruption of "this world" by the Christian message. ${ }^{91}$ Marriage is a conservative metaphor, and continence a countermetaphor discharged from the camp of the Christians.

I agree that focusing simply on the liberatory aspects of the Acts (such as they are) may not be as fruitful as was once imagined (although the impact on aristocratic women of later centuries who read these Acts is noteworthy). ${ }^{92}$ In addition to anachronistically projecting modern conceptions of marriage and feminist liberation into antiquity, ${ }^{93}$ such an approach also ignores the fact that it is precisely in the period of the composition and dissemination of the Apocryphal Acts that marriage

popularized the notion that "many of the apocryphal Acts were written by women" (95); his thesis was to some extent accepted by Dennis R. MacDonald, The Legend and the Apostle: The Battle for Paul in Story and Canon (Philadelphia: The Westminster Press, 1983), 33-53, who suggested instead female "storytellers" but male "writers"; Virginia Burrus, Chastity as Autonomy: Women in the Stories of the Apocryphal Acts. Studies in Women and Religion, no. 23 (Lewiston/Queenston: The Edwin Mellen Press, 1987) proceeds from both of these points of view to examine the "folkloristic" nature of these "women's chastity stories." See also Elisabeth Schüssler Fiorenza, "Word, Spirit and Power: Women in Early Christian Communities," in Rosemary Ruether and Eleanor McLaughlin, eds., Women of Spirit: Female Leadership in the Jewish and Christian Traditions (New York: Simon \& Schuster, 1979), 2970, esp. 37-39.

89. Brown, Body and Society, 153.

90. Cooper, Virgin and the Bride, 55.

91. Cooper, Virgin and the Bride, 58-62. For a critique of this "political" reading of the novels and Apocryphal Acts, see the review of Cooper, Virgin and the Bride, by Judith Evans Grubbs in Classical Philology 93 (1998): 201-9. I thank one of the anonymous JECS readers for directing me to this review.

92. See Cooper, Virgin and the Bride, 67-72; and Clark, "Antifamilial Tendencies," 371-80.

93. See Gillian Clark, Women in Late Antiquity: Pagan and Christian Lifestyles (Oxford: Clarendon Press, 1993), 4: "There is no certainty that our own dissatisfaction was shared by women of the time, whose experience and expectations were so different from our own." 
was beginning to attain its familiar configuration. ${ }^{94}$ More than mere cipher, marriage was being deployed to reconstruct family ethics, to redirect the lines of authority and morality within the family structure of a certain class. Men and women giving up sex may tell the story of asceticism and subversion, but men and women giving up marriage tell a story about families and Christian ethical resistance along social status lines.

I have suggested above that this new marital ethics may have been translated into less appropriate (i.e., lower class) social spheres. Interestingly, it is generally only the scholars writing "against the grain" who point out the social exclusivity of iustum matrimonium: Bernadette Brooten and John Boswell, writing to carve out a historical space for same-sex unions in antiquity, emphasize the restrictedness of ancient marriage to very particular social classes. ${ }^{95}$ Paul Veyne, concerned to "de-Christianize" the foundations of modern ethics, states it baldly:

All the transformations of sexuality and conjugality are anterior to Christianity. Two principal shifts come to pass, from a bisexuality of penetration to a heterosexuality of reproduction; and from a society where marriage is in no way an institution designed for all society to a society where it "goes without saying" that marriage ("le" mariage) is a fundamental institution of all societies (so one believes) and of society in its entirety. In pagan society, everyone did not get married. . . . One married in one sole case: if one decided to transmit one's fortune to one's children. ${ }^{96}$

Veyne goes on to describe the social and class implications of this universalizing ethical shift. ${ }^{97}$ His focus, however, is how the spread of a

94. Dixon, "Sentimental Ideal," 99: "From the late Republic on, it is possible to discern a sentimental ideal of family life at Rome which can be compared with our own cultural ideal. The expectation of affection within marriage and the appreciation of young and youthful children were both part of this ideal.”

95. Bernadette Brooten, Love Between Women: Early Christian Responses to Female Homoeroticism (Chicago: The University of Chicago Press, 1996), 333-34; John Boswell, Same-Sex Unions in Premodern Europe (New York: Villard Books, 1994), 31-38; compare the unsupported statement of Egger, "Women and Marriage," 261: "To [the novelists] the whole world is married (as most people, we may presume, actually were ....)."

96. Veyne, "Famille et l'amour," 39-40, emphasis mine. See also Paul Veyne, "The Roman Empire," in idem, ed., A History of Private Life, vol. 1: From Pagan Rome to Byzantium, trans. A. Goldhammer (Cambridge: Harvard University Press, 1987), 16233, here 36: "At some point people began to internalize, as a moral code, what had been a civic and dotal institution. . . . Note, however, that everything I am about to say applies to only a tenth or a twentieth of the free population, to the class of the wealthy, who also considered themselves cultivated."

97. Veyne, "Famille et l'amour," 48. 
new marital ethics affected the discourse of sexuality; as marriage became the ethical center of society's institutions, however, it also threatened to eclipse other moral configurations of the family. Accepting Veyne's proposal that as this new ethics became interiorized it was also universalized, and having traced one route by which this upper-class discourse might have penetrated to lower classes, I would now like to frame the Apocryphal Acts of the Apostles as a deliberate form of narrative resistance to this ethical family configuration centered on marriage.

For most of this century the generic ties between the Greek romance and the Apocryphal Acts have been acknowledged and explored. ${ }^{98}$ When it was imagined that the Greek novels were a sort of popular literature, intended for women or other "juvenile" readers, it seemed natural to imagine the Apocryphal Acts appealing to an analogous audience on similar grounds. Scholars have now conceded that the novels were intended for a more sophisticated audience, occasionally penetrating to a "wider" readership; the Apocryphal Acts, however, still seem the province of a lower-class audience, ${ }^{99}$ and thus the strange liberties and inversions of "romantic" themes in the Acts have been read more and more as incidents of political and social subversion. Judith Perkins maintains "that in the so-called Apocryphal Acts of the Apostles signs and strategies of an emerging representational and social challenge are preserved," 100 and charts the many examples of class- and statusoriented resistance in the Acts of Peter. While Perkins focuses on the subversion of essentially "public" social institutions and their reconfiguration around a new model of subjectivity, I would like to redirect her inquiry into the models of family and kinship as reconfigured in the Apocryphal Acts. As I observed in my introduction, there is a deliberate

98. Rosa Söder, Die apokryphen Apostelgeschichte und die romanhafte Literatur der Antike (Stuttgart: W. Kohlhammer, 1932), 181: "Romanhafte Erzählungen-das dürften die vorgelegten Untersuchungen klargemacht haben-sind auch die AGG [apokryphen Apostelgeschichte]." Cooper claims of the Greek romance and Apocryphal Acts that "neither genre can be fully understood without reference to the other" (Virgin and the Bride, 22). For comparative studies between Söder and Cooper, see Cameron, Christianity and Rhetoric, 90 n. 1.

99. As discussed by Perkins, Suffering Self, 124-25, 138-41, drawing mainly on literary style and the various "sympathies" played out in the Acts of Peter.

100. Perkins, Suffering Self, 124. See also Cooper, Virgin and the Bride, 66-67; and Melissa Aubin, "Reversing Romance? The Acts of Thecla and the Ancient Novel," in Ronald Hock, Brad Chance, and Judith Perkins, eds., Ancient Fiction and Early Christian Narrative. SBL Symposium Series, no. 6 (Atlanta: Scholars Press, 1998). 
emphasis in many of the Apocryphal Acts on the disastrous intervention of the apostle into a conjugally oriented family. ${ }^{101}$

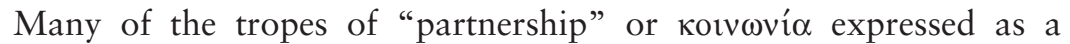
marital ethics in the classical literature are subverted in the Acts, and

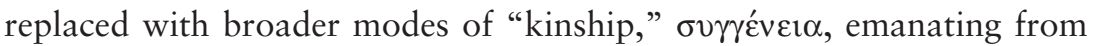
the authority of the apostle. The Acts of Andrew, for instance, distort the philosophically beneficial "procreation" lauded by Plutarch: while Plutarch had transformed the bedroom into an "ethical schoolhouse," the author of the Acts of Andrew converts the bedroom of the heroine, Maximilla, into a Christian meeting place. ${ }^{102}$ One of the more bizarre moments in the Acts of Andrew comes when Maximilla's husband Aegeates, proconsul of Achaea, returns to the palace while the Christians are meeting in his bedroom; as he sits outside the bedroom on a chamberpot, Andrew "seals" the Christians so they can pass by unseen. ${ }^{103}$ After they have all departed, Aegeates rushes into the bedroom and attempts to change it once more into a place of conjugal union. Aegeates' words to his wife might come from the Coningalia praecepta: "Give me your right hand first: I shall kiss her whom I no longer call 'wife' ( $\gamma v v \alpha i \kappa \alpha)$ but 'mistress'

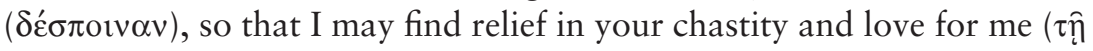

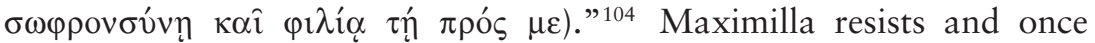
Aegeates has fallen asleep she sends for Andrew so they may meet in "another bedroom." ${ }^{105}$ Much of this section of the Acts of Andrew takes place in various bedrooms of the proconsular praetorium in Patras; ${ }^{106}$ both the tender speeches delivered by Aegeates to his wife and the

101. For generic and textual studies of the "five main" Apocryphal Acts, see the essays in F. Bovon et al., eds., Les Actes Apocryphes des Apôtres: Christianisme et monde païen (Geneva: Labor et Fides, 1981), especially the useful appendix of date and provenance for each of the Acts (289-305). See also the recent article by David Konstan, "Acts of Love: A Narrative Pattern in the Apocryphal Acts," JECS 6 (1998): 15-36, on narratives of "familial affection and integration" in the Apocryphal Acts.

102. Passio Andreae 13 (MacDonald 340), the "brethren assemble on the Lord's day in Aegeates' bedroom."

103. Passio Andreae 13-14 (MacDonald 340-42).

104. Passio Andreae 14 (MacDonald 342).

105. Passio Andreae 15 (MacDonald 344).

106. The action in Patras begins in this portion of the Acts of Andrew with Maximilla "leaving her bedroom" to greet her brother-in-law Stratocles (Passio Andreae 1 [MacDonald 326]); she likewise "emerges from her bedroom" when Stratocles' servant is possessed (Passio Andreae 2 [MacDonald 326]); Andrew's conversion speech to Stratocles takes place in Maximilla's bedroom (Passio Andreae 6-8 [MacDonald 332-34]); and it is likely that the baptism of the "brethren" also takes place in this elaborate network of bedrooms (Passio Andreae 10-12 [MacDonald 336-40]). 
sermons delivered by Andrew to his "brethren" make clear that the locus of elite conjugal koinonia is being actively transformed into a site of sacred sungeneia. Although Andrew and Maximilla characterize Aegeates' desires as "filthy intercourse" and a "foul and sordid way of life," 107 Aegeates himself echoes the ethical configuration of marriage found in the philosophical and romantic literature. Sex for Aegeates represents a higher union; when he discovers that Maximilla has been sending a slave-girl to his bed in her place, he does not reproach his wife with threats and potestas but beseeches her in language of partnership and union: "I cling to your feet, having lived with you as your husband ( $\dot{\alpha} v \grave{\rho} \rho$

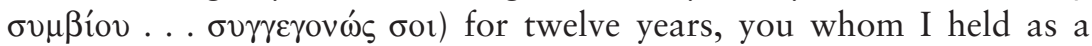
goddess and now I still hold you as such on account of your chastity ( $\sigma \omega \varphi \rho \circ \sigma u ́ v \eta \varsigma)$ and your generally refined character." 108 Later, when Maximilla persists in their separation even while Andrew sits in prison, Aegeates again attempts to win her back. His description of their nuptial bond sets aside the typical worldly concerns of marriage and emphasizes their spiritual and ethical union, even in sexual intercourse:

Maximilla, because your parents thought me worthy to be your mate ( $\tau \hat{\text { }} \mathrm{s}$ $\sigma v \mu \beta i \omega \sigma \varepsilon \omega ́(\sigma o v)$, they pledged you to me in marriage without regard to wealth, heredity or reputation, considering only the kindness of my soul. ... If you would be the woman you once were, living together with me $\left(\sigma \nu \mu \beta \imath{ }^{\prime} \sigma \alpha \mu o t\right)$ as we were accustomed, sleeping with me, consorting with

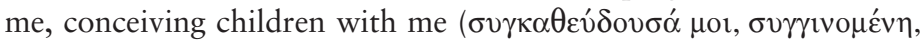
$\sigma \cup v \tau \varepsilon \kappa v o v \overline{\sigma \alpha}$ ), then I would treat you well in every way. ${ }^{109}$

Sharing a bed, having sex, and bearing children are all subordinate aspects of "living together," which for Plutarch had been the highest form of companionship. ${ }^{110}$

Maximilla rejects Aegeates' soulful union, however, and is "seduced" away by a competing rhetoric of family. ${ }^{111}$ That this moral superiority is couched in familial terms is not insignificant: throughout the Patras episode of the Acts of Andrew, there is repeated emphasis on sungeneia. ${ }^{112}$ Andrew's speeches not only refer to the Christian converts as "brethren,"

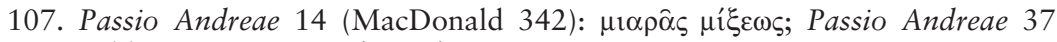

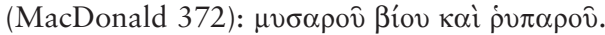

108. Passio Andreae 23 (MacDonald 352).

109. Passio Andreae 36 (MacDonald 370).

110. See Plutarch, Coniugalia praecepta 34 (142F-43A: LCL 2: 324).

111. Cooper, Virgin and the Bride, 46-67, esp. 56-60, demonstrates that the "rivalry" for the fidelity of one woman was designed to demonstrate the "moral superiority" of the apostolic hero over his pagan (often imperial) counterpart.

112. See MacDonald, Acts of Andrew, 331 n. 7. 
they reconstruct the diverse body of believers into a family of God united around the apostle: "If you desire a friend who supplies goods not of this world, I am your friend. If you desire a father for those who are rejected on earth, I am your father. If you desire a legitimate brother ( $\alpha \delta \varepsilon \lambda \varphi \grave{v} v$ $\gamma v$ í⿴囗⿱一一) to set you apart from bastard brothers, I am your brother." ${ }^{113}$ The first time Maximilla refuses to sleep with Aegeates, and meets instead with Andrew in "another bedroom," the apostle commends her choice and prays to God, "If she has such a firm faith in you, may she obtain her own proper kinship ( from those who affect such ( $\tau \hat{\omega} v \pi \rho 0 \sigma \pi \mathrm{o} \eta \tau \hat{\omega} v)$ but are really enemies." 114 By intervening in what might seem the correct familial context for the wife of a Greek proconsul, and providing instead a "truer" and morally superior family life, Andrew demonstrates the deficiency of the conjugally-oriented family.

Significantly, the particular status of that conjugal family is not masked in the Apocryphal Acts as it was in the Greek novel: the failure of this familial configuration is linked throughout with its upper-class milieu. Compare the ambiguously paired house-slaves Leukon and Rhode, who enjoy a (perhaps brief?) married family life, with the "wanton slave-girl" Euclia in the Acts of Andrew. Sent by Maximilla to be "used" by Aegeates "as his lover" and take Maximilla's place in the marriage bed, Euclia grows boastful and demands money and her freedom from her mistress (gifts Leukon and Rhode receive easily from their master in Lycia before beginning a life of conjugal bliss). Resented by her fellow-slaves, Euclia is betrayed and the "furious proconcul" cuts out her tongue and casts her outside, where she becomes "food for the dogs." ${ }^{115}$ The marriage bed is evidently a dangerous place for slaves. In the novels, class was veiled to the point that a slave could be elevated into the ethically superior family constructed by marriage; in contrast, in the Apocryphal Acts those wealthy aristocrats instead "drop down" socially into the inferior state of the other "brethren." This inversion of the ethical universalization of the novels is represented by the figure of Stratocles, Aegeates' brother.

113. Passio Andreae 12 (MacDonald 338-40).

114. Passio Andreae 16 (MacDonald 346). MacDonald assumes that the $\pi \rho 0 \sigma \pi$ oin $\tau \hat{\omega} v$ are "masquerading friends," but the emphasis in the entire work on "true" and "false" kin suggests to me instead "pretend" families. Since Aegeates is repeatedly referred to as the son or relative of demons (see for example Passio Andreae 40 [MacDonald 378]), as Maximilla's husband he is the worst of these pretenders.

115. Passio Andreae 17-22 (MacDonald 346-52). A fate reminiscent of that preeminent harlot Jezebel (II Kgs 9.34-37). 
Like Pollianus and Eurydice in the Coningalia praecepta, Stratocles is first distinguished in the Acts of Andrew as spiritually and ethically advanced: he is "Aegeates' brother, who had petitioned Caesar not to serve in the army but to pursue philosophy." 116 Furthermore he endures a crisis like those of the "best friends" in the Greek novels: Alcman, "a boy whom Stratocles loved dearly," falls violently ill and Stratocles blames himself. "If only I had never come here but perished at sea this would not have happened to me! Friends . . . I cannot live without him." 117 If this were a scene from one of the Greek novels, Alcman would die and Stratocles' brother Aegeates would initiate a brief discourse on the benefits of married life over pederasty; we are far from the land of romance, however. Instead Maximilla fetches Andrew, who promptly heals Alcman and engages Stratocles in a further inversion of the Platonic love-discourse mimicked in Leukippe and Kleitophon. ${ }^{118}$

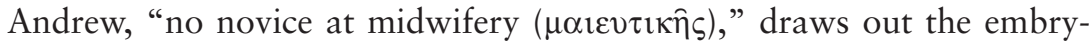
onic "new self" trapped inside Stratocles. Andrew recognizes that "whatever [Stratocles'] former philosophy, he now knows that it was hollow." "119 Stratocles gives up all his possessions (an act he manages to repeat after his baptism) $)^{120}$ and through Andrew's care his "embryos" are "brought into the open, so that they may be registered by the entirety

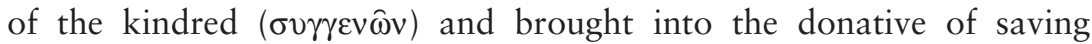

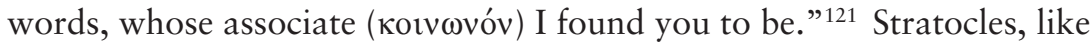
Maximilla, enters into his own "proper kinship" with his fellow Christian believers, one of whom is his (presumably former) young lover Alcman. ${ }^{122}$ Leukon and Rhode had moved "upwards" into a marital relationship marked by gentility and munificence; Stratocles in contrast moves "down" into a kinship marked by humility and subservience. One of Aegeates' servants reports to his master that "even though [Stratocles]

116. Passio Andreae 1 (MacDonald 326). There is an ironic pun on Stratocles'

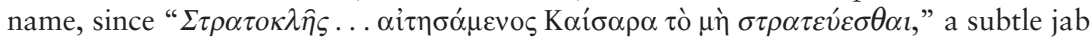
at upper-class generals who philosophize in their spare time (perhaps most famously Caesar himself).

117. Passio Andreae 2 (MacDonald 326).

118. Passio Andreae 5-6 (MacDonald 330-32).

119. Passio Andreae 7 (MacDonald 334).

120. Passio Andreae 8, 12 (MacDonald 334, 340).

121. Passio Andreae 9 (MacDonald 336).

122. Passio Andreae 10 (MacDonald 336). Konstant, “Acts of Love," 20, uses this story to argue that the "apostle does not destroy human bonds of affection, except insofar as they necessarily involve sex." I find his argument persuasive, but would add that not only sex but class serves to determine which "bonds of affection" are to be resisted by Christian fellowship. 
owns many slaves, he appears in public doing his own chores—buying his own vegetables and bread, and other necessities and carrying them on foot through the center of the city-making himself look simply repulsive to everyone." 123 This Christianized family ethics is again inscribed as "lower class" at the end of the Acts of Andrew; after Andrew has faced martyrdom, Maximilla separates herself from the proconsular household and spends "her time happily with the brethren." When Aegeates kills himself in dejection, Stratocles for a third time renounces wealth and station: "Stratocles ... did not want so much as to touch the property Aegeates left-for the wretch died childless. He said, 'May your possessions go with you, Aegeates! May Jesus be my friend!" "124 The marital union has failed on all counts-not even children were produced—and this failure is linked to the literal fortunes of an aristocratic family.

This eradication of the upper-class conjugal family ethics is articulated variously throughout the Apocryphal Acts of the Apostles, sometimes with more subtlety than the devastated family in Patras. In the Acts of John the apostle gathers a collection of formerly wealthy married couples into his wandering circle of believers. The first extant portion of the Acts of John portrays the apostle arriving at Ephesus, greeted by the forlorn general Lycomedes ("a wealthy man") whose wife has fallen ill. Both Lycomedes and John speak of the fallen woman, Cleopatra, as a beloved wife and partner. Lycomedes cries out that if Cleopatra dies he will follow her, and John immediately promises that his "partner for life ( $\tau \eta$

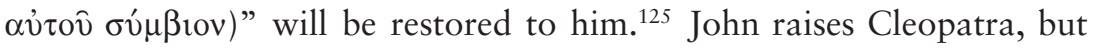
not before Lycomedes himself falls down and seems dead. So the scene repeats itself, with Cleopatra threatening to die unless Lycomedes is raised; when both husband and wife are restored, they fall to John's feet and beg him and his "companions" to stay with them in their house. John is persuaded by his disciples to transform the house of the married couple into the meeting place of the Christians in Ephesus, "so that they

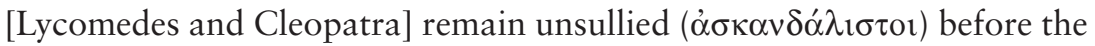
Lord." ${ }^{126}$ Here there is no need to defeat a male rival in order for his wife

123. Passio Andreae 25 (MacDonald 356).

124. Passio Andreae 64 (MacDonald 438).

125. Acta Ioannis 19-21. Text in Lipsius and Bonnet, Acta Apostolorum, 2.1: 151-216, here 161-62. Translated in Elliott, Apocryphal New Testament, 310-45, here 311-12.

126. Acta Ioannis 24-25 (Lipsius-Bonnet 2.1: 164-65; Elliott 313). Their house continues as the meeting place of Ephesian Christians in this section: see Acta Ioannis 26, 31 (Lipsius-Bonnet 2.1: 165, 167; Elliott 313, 315). 
to become a continent Christian, and what had been a conjugal union based on affection and reciprocity is more neatly subsumed into a larger Christian sungeneia. A duplicate story in the Acts of John (now lost) seems to have presented a rockier road to Christian kinship, but a similar ending: Drusiana, wife of a wealthy Ephesian named Andronicus, had been persuaded by John to remove herself from her husband's bed. Later in the Acts other Ephesians recount the tale to a lusty admirer of Drusiana: "Do you alone not know that Andronicus, who was not the godly man he now is, had locked her up in a tomb, saying, 'Either I'll have you as a wife, as I had you before, or you must die?" 127 The situation recalls that of Aegeates and Maximilla; at the point in the Acts of John that this story is being recounted, however, Andronicus has been "persuaded to become like-minded," 128 travels chastely with his wife in John's apostolic entourage ${ }^{129}$ and, like Lycomedes, offers his Ephesian house as a meeting-place for John's followers. ${ }^{130}$ Once again, the chaste couple allows their well-off conjugal family to be swallowed up by the more common Christian kinship led by the apostle. Like Andrew, John is a "father" to the brethren who set aside the things of this world to become his "children" and his "servants"; at one point we are treated to a catalogue of believers who move with John across Asia Minor: "Andronicus and Drusiana, Lycomedes and Cleobius, and their attendants. ... Aristobula, who had heard that her husband Tertullus had died on the way, Aristippus with Xenophon, and the chaste prostitute (i $\sigma \omega \dot{\varphi} \rho \omega v \pi$ ó $\rho \eta)$, and many others." 131 A motley crew of nobles, servants, repentant harlots, and others who are articulated primarily as members of an itinerant Christian "family."

Marriage, as in the Greek novels, could also be disrupted before the bride and groom had consummated their nuptial union. This occurs in the house of Thecla, still affianced to Thamyris when Paul breezes into town and sets her household on its head. Breaking her bond with Thamyris, and with it the validity of the conjugal union itself, for Thecla entails renunciation of wealth and station; her first visit to Paul in prison witnesses Thecla handing over her bracelets and silver mirror to the

127. Acta Ioannis 63 (Lipsius-Bonnet 2.1: 181-82 ; Elliott 329).

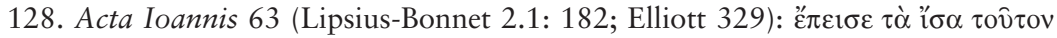

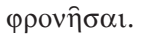

129. Acta Ioannis 59, 105 (Lipsius-Bonnet 2.1: 180, 203; Elliott 328, 322).

130. Acta Ioannis 46, 62 (Lipsius-Bonnet 2.1: 173, 181; Elliott 324, 328).

131. Acta Ioannis 59 (Lispius-Bonnet 2.1: 180; Elliott 328). Some MSS read "Cleobis" instead of Cleobius, perhaps signifying that the two couples, Andronicus and Drusiana, Lycomedes and Cleopatra, were once listed here. 
jailers in order to gain entry. ${ }^{132}$ In surrendering these precious items, Thecla symbolically surrenders her gendered social status as a "cultivated" wife. ${ }^{133}$ She who was once "first" among the Iconians becomes a "slave of God." 134 Even more dramatic is the treatment of the apostle Peter's own daughter in a Coptic fragment of the Acts of Peter. As a beautiful young girl his daughter becomes a "stumbling-block," and a "very rich man, Ptolemy by name ... sent for her to take her for his wife." 135 Although the text is fragmentary, it seems that the Peter asked the Lord to paralyze the girl to make her less desirable; Ptolemy, on the brink of suicide (Aegeates' fate in the Acts of Andrew), is stopped by a vision and converted to following Christ. Upon his death, he leaves land to Peter's daughter which the apostle promptly sells to give "the whole sum to the poor." 136 Wealth and marriage narrowly avoid colliding with the morally superior (i.e., poor) family of the apostle, here represented by a literal daughter (although at one point Ptolemy's vision refers to her also as "your sister").

The long and involved Acts of Thomas were probably originally composed in Syriac, but were quickly translated into Greek and transmitted through the same milieux as the other Apocryphal Acts of the Apostles. ${ }^{137}$ The affinities of the Greek recension of the Acts of Thomas with the discourse of marital ethics on the rise in the Greco-Roman world allow us to bring together the different scenarios of marital and familial disruption accomplished by an apostle. The first intervention occurs at the moment of marital consummation. Having recently been sold by a vision of Jesus (his twin brother) to an Indian merchant,

132. Acta Pauli et Theclae 18 (Lipsius-Bonnet 1: 247; Elliott 367).

133. On the class- and gender-specific significations of bracelets and mirrors, see Maria Wyke, "Woman in the Mirror: The Rhetoric of Adornment in the Roman World," in Léonie J. Arches, Susan Fichler, and Maria Wyke, eds., Women in Ancient Societies: An Illusion of the Night (New York: Routledge, 1994), 134-51.

134. Acta Pauli et Theclae 26 (Lipsius-Bonnet 1: 254; Elliott 369).

135. Acta Petri 132 in D. M. Parrott, ed., Nag Hammadi Codices V, 2-5 and VI with Papyrus Berolinensis 8502, 1 and 4. Nag Hammadi Studies, no. 11 (Leiden: E. J. Brill, 1979), 473-93, here 482-84; translated in Elliott, Apocryphal New Testament, 397-98.

136. Acta Petri 135-39 (Parrott 484-90). See Parrott's note on 484-85, using a notice by Augustine to restore the cause of Peter's daughter's paralysis. For a study of the role of wealth and class in the rest of the Acts of Peter, see Perkins, Suffering Self, 124-41.

137. On the textual history of the Acts of Thomas, see A. F. J. Klijn, The Acts of Thomas: Introduction, Text, Commentary (Leiden: E. J. Brill, 1962), 1-17; on the parallels and possible literary connections between the Acts of Thomas and the other early Apocryphal Acts, 18-26. 
Thomas finds himself attending the wedding of the only daughter of the king of Andrapolis. ${ }^{138}$ At the wedding reception he chants a hymn and is taken by the king to pronounce a blessing on his daughter and her husband. His words sound innocent enough: "I beseech you, Lord Jesus, offering you supplication for these young persons, that you may do to them what helps, benefits, and is profitable for them." ${ }^{139}$ Immediately afterwards in the wedding chamber, however, a vision of Jesus "in the appearance of Judas Thomas" reveals these "benefits":

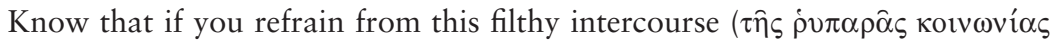

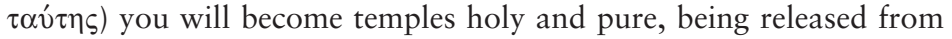
afflictions and troubles. ... If you beget many children, for their sakes you will become grasping and avaricious, plundering orphans and deceiving widows. ... But if you obey and preserve your souls pure to God, there will be born to you living children, untouched by these hurtful things, and you will be without care, spending an untroubled life, free from grief and care, looking forward to receive that incorruptible and true marriage, and you will enter as groomsmen into that bridal chamber full of immortality and light. ${ }^{140}$

The "benefits" of marriage, companionship and procreation, are spiritualized and their corruptible elements eliminated. The next morning the unveiled bride announces proudly to her father the king, "And that I

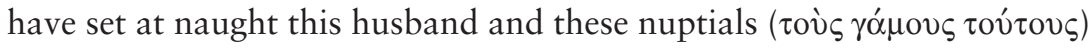
which have passed away before my eyes is because I have been joined in a different marriage $(\dot{\varepsilon} \tau \dot{\varepsilon} \rho \omega \gamma \alpha \dot{\alpha} \mu \omega)$. . . . I have been united to the true husband." ${ }^{141}$ A certain rhetoric of marriage is maintained, but sufficiently spiritualized to allow its force to be subsumed into that of the Christian "family." Thomas sails away with his master to India, but we are told that a Hebrew slave who had served at the wedding "rejoiced greatly" upon hearing that the couple had chosen to remain continent: "And she arose and went to them, and was with them a long time, until they had

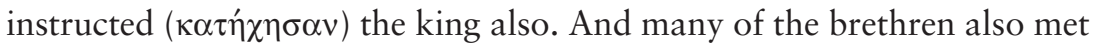
there, until the rumor had spread that the apostle had gone to the cities of India and was teaching there. And they went away and joined him."142 Although Thomas' intervention was brief (in fact the apostle's role in this conversion is unclear) the scenario is by now a familiar one:

138. Acta Thomae 4. Text in Lipsius and Bonnet, Acta Apostolorum, 2.2: 99-208, here 104-6. Translation in Elliott, Apocryphal New Testament, 447-511.

139. Acta Thomae 10 (Lipsius-Bonnet 2.2: 115; Elliott 451).

140. Acta Thomae 12 (Lipsius-Bonnet 2.2: 116-18; Elliott 452).

141. Acta Thomae 14 (Lipsius-Bonnet 2.2: 120; Elliott 453).

142. Acta Thomae 16 (Lipsius-Bonnet 2.2: 123-24; Elliott 453-54). 
a couple turns away from an upper-class marital union upon learning its moral deficiencies, and instead enters into a spiritualized marriage in turn subordinated to their new "kinship," in which their "brethren" could as easily be slaves as kings.

In India Thomas performs a series of miracles instigated by the disastrous consequences of love, marriage, and status: he heals a woman whose renunciation of sex was abrogated by a demon who chose to live with her "as man and wife"; ${ }^{143}$ he cures the withered hands of a man who had slain his lover when she refused to live with him "in chaste and pure conduct," and then raises the woman herself from hell; ${ }^{144}$ and he casts out the demons from an Indian captain's wife and daughter, who had been possessed since their unwilling attendance at a wedding. ${ }^{145}$ These incidents slowly chip at the moral edifice of marriage. Finally the Acts of Thomas strikes at the upper-class core when Thomas is heard preaching by Mygdonia, "wife of Charisius the near relative of the king." 146 Like a disease, Thomas' disastrous message of sexual and marital renunciation spreads through the royal family: Mygdonia converts, followed by Tertia, the king's wife, and Vazan and Mnesara, the king's son and daughter-in-law. Like Thecla, Mygdonia finds that renunciation of her married state entails surrendering her wealth and status. Thomas tells her that "neither the fame of the authority which surrounds you nor the power of this world nor this filthy intercourse $(\dot{\eta}$

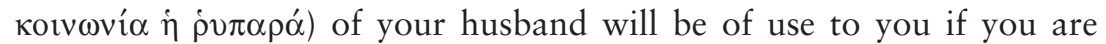
deprived of the true intercourse." ${ }^{147}$ She gives up her finery and wallows

143. Acta Thomae 42-49 (Lipsius-Bonnet 2.2: 159-66; Elliott 465-67). The

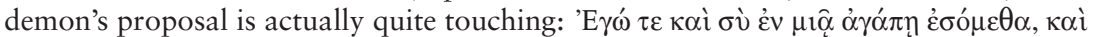

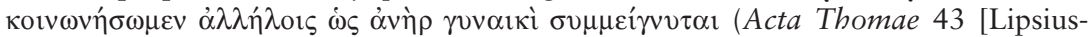
Bonnet 2.2: 160]). A possible allusion might be heard to the situation between Sarah and the demon Asmodeus in the Book of Tobit, with Thomas subverting the role of Tobias.

144. Acta Thomae 51-59 (Lipsius-Bonnet 2.2: 167-77; Elliott 468-72).

145. Acta Thomae 62-81 (Lipsius-Bonnet 2.2: 178-97). The captain, Siphor, later offers his home to Thomas as a meeting-place, like Lycomedes and Andronicus in the Acts of John (Acta Thomae 131 [Lipsius-Bonnet 2.2: 238-39]). The setting of a wedding ( $\gamma \alpha \dot{\alpha} \mu \mathrm{ov})$ is more precise than the ambiguous term "banquet" (mashtotah) used in the Syriac (text in William Wright, ed., Apocryphal Acts of the Apostles, vol. 1: The Syriac Texts [Amsterdam: Philo Press, 1968], 172-333, here 232; see Klijn, 255).

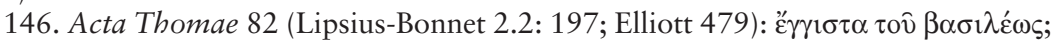
this formula is repeated throughout the rest of the Acts of Thomas, like a Homeric epithet: see Acta Thomae 87, 89, 93, 95, 102, 134, 135 (Lipsius-Bonnet 2.2: 202, 204, 206, 208, 215, 240, 241).

147. Acta Thomae 88 (Lipsius-Bonnet 2.2: 203; Elliott 481). 
on the ground in sackcloth and ashes; her husband Charisius laments "the madness of the stranger, whose tyranny throws the great and illustrious into the abyss. . . . her noble soul has been humbled." 148 Charisius pleads with her time and again, as Aegeates pleaded with Maximilla, to restore not just their marriage bed but their sacred bond: "You are my riches and honor, you are my family and kindred!" 149 Charisius cannot convince his wife, nor later the king his queen, that the noble marriage bond which they believed would be ethically edifying and fulfilling is anything but a pale shadow of the superior kinship found in Christianity.

When the fledgling Christian community gathers on the eve of Thomas' martyrdom, his prayer reconfigures them as a family of harassed, impoverished wanderers, huddling for life and security around the bright light of Christ: "Companion and associate," he prays, "hope of the weak and trust of the poor, refuge and shelter of the weary, voice which came forth from on high, comforter who dwells among us, shelter and haven of those who travel through dark countries. . . . be with Vazan, Misdaeus' son, and Tertia and Mnesara, and gather them into your fold and unite them with your number." ${ }^{150}$ One might never suspect from such a baptismal prayer that the baptizands being prayed for are of the Indian royal family. The familial configuration which might have marked their noble status, the conjugal union, has been beaten back, and with it disappear notions of worldly hierarchy and class: the mere captain becomes a priest at the end, and the king's son his deacon. ${ }^{151}$ Eventually even King Misdaeus of India, after years of resistance, is transformed into merely one of "the multitude of those who had believed in Christ." ${ }^{152}$

\section{CONCLUSIONS: THE NEW FAMILY CIRCLE}

The narrative canvas on which the authors of these Apocryphal Acts painted their family portraits resembles a twisted, abstracted representation of the romantic ideal of philosophers and novelists. The well-born heroes and heroines of novel are precisely the figures who must discover

148. Acta Thomae 135, 99 (Lipsius-Bonnet 2.2: 241, 211-12; Elliott 498, 485).

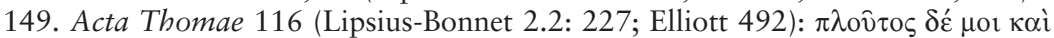

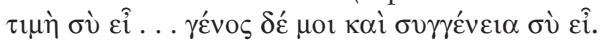

150. Acta Thomae 156 (Lipsius-Bonnet 2.2: 264-65; Elliott 504).

151. Acta Thomae 169 (Lipsius-Bonnet 2.2: 284-85; Elliott 510).

152. Acta Thomae 170 (Lipsius-Bonnet 2.2: 287; Elliott 511). 
the moral and ethical failure of the marital ideal proposed to them by their elders: Thecla would not have the same impact in the Acts of Paul were she not one of "the first of Iconium." The king of Andrapolis must be catechized by his (former?) slave-girl, and a new kinship patterned on absolute renunciation and subservience to an apostolic father must transform the bedroom into a new and better "ethical schoolhouse." When analyzing early Christian discourse, however, we must never lose sight of its conscious reliance on rhetoric and representation; $;^{153}$ it would be simplistic and fallacious to assume that a truly gritty lower class produced these texts that celebrate the failure of a dangerously romanticized upper-class family ethics.

Instead I would like to place these rich narratives in the same stream of Christian rhetoric that permitted the educated author of the Third

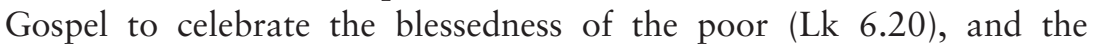
astonishingly well-read third-century exegete Origen happily to accept Celsus' criticism that Christians are "the most illiterate and bucolic yokels," and turn it to his advantage. ${ }^{154}$ Judith Perkins has suggested that in the first centuries of Christianity a subjectivity constructed around suffering was deployed to empower Christian communities. ${ }^{155}$ Narratives of pain and subjugation do not necessarily tell the historical story of martyrdom and "real" suffering, but rather construct a resistant and subversive identity. So, too, in the Apocryphal Acts of the Apostles, the family as locus of ethical progression is bifurcated into a failed upperclass family, represented by the increasingly popular ideal of the conjugal union, and a more ethical mode of Christian "kinship," sungeneia, instituted by the homewrecking apostle and bringing down the swashbuckling hero of romance into a "simply revolting" brotherhood of slaves, kings, and women. Christians in these circles embraced the character of the cultural and societal Other, and deployed this otherness as a rhetorical device in discursively fruitful battles over "family values." While not necessarily emanating from the seediest depths of imperial

153. See the useful remarks of Cameron, Christianity and Rhetoric, 36-39.

154. Origen, Contra Celsum 3.55-60 (SC 136: 128-40). Translated in Henry Chadwick, Origen: Contra Celsum (Cambridge: Cambridge University Press, 1965), 165. See Cameron, Christianity and Rhetoric, 111: "The Pauline claim to truth-in constrast to the "wisdom of the world'-could be turned to good effect, converting charges of uncouth lack of refinement into claims of simplicity and truth." See also Dale Martin, Slavery as Salvation: The Metaphor of Slavery in Pauline Christianity (New Haven: Yale University Press, 1990), 147-49.

155. Perkins, Suffering Self, 12 and 104-23. 
society, ${ }^{156}$ Christians writers could construct themselves into a lowly position and gloat to their pagan neighbors that their "families" were morally superior and that their garments remained whiter than the polluted bedclothes of married Greeks and Romans. It is one of the truly fascinating developments of early Christian discourse and identity that once the political and social position of Other is no longer as tenablewhen Christians "triumph" and Christianity settles into the limits of empire- these rhetorical manipulations of family and kinship take on a "real" existence, prompting generations of wealthy and noble-born Theclas (such as Macrina and the Melaniae) to live out these "strange stories" and seek ethical and moral advancement by denouncing the shameful state of that "lifelong partnership" of marriage.

Andrew S. Jacobs is a doctoral candidate in the Graduate Program in Religion at Duke University

156. On the probable status of first- and second-century urban Christians, see Meeks, First Urban Christians, 51-73: "It is a picture in which people of several social levels are brought together. The extreme top and bottom of the Greco-Roman social scale are missing from the picture" (72-73). 